\title{
Synthesis of Nickel Zinc Iron Nanoparticles by Coprecipitation Technique
}

\author{
Kandasamy Velmurugan ${ }^{\mathrm{a}, *}$, Vellaiyappan Sangli Karuppanan Venkatachalapathy ${ }^{\mathrm{b}}$, \\ Sechassalom Sendhilnathan ${ }^{c}$ \\ ${ }^{a}$ Sri Chandrasekharendra SaraswathiViswa, Maha Vidyalaya University, \\ Kanchipuram, 631561, India \\ ${ }^{b}$ Principal, Sri Manakula Vinayagar Engineering College, Pondicherry, 605107, India \\ ${ }^{c}$ Assistant Professor, Department of Physics, Anna University Tiruchirappalli, \\ Pattukkottai Campus, Thanjavur Dist., 614701, Tamil Nadu, India
}

Received: November 21, 2009; Revised: March 10, 2010

\begin{abstract}
Nanoparticles nickel ferrite of size $6-8 \mathrm{~nm}$, synthesized by the coprecipitation method with $\mathrm{x}$ varying from 0 to 1.0. The powder samples were characterized by XRD, VSM and FTIR. The average crystallite sizes of the particles were determined from X-ray diffraction. X-ray analysis showed that the samples were cubic spinel. The lattice constant $\left(\mathrm{a}_{\mathrm{o}}\right)$ increased with the increase in zinc substitution. The specific saturation magnetization $\left(\mathrm{M}_{\mathrm{S}}\right)$ of the particles was measured at room temperature. The magnetic parameter of $\mathrm{M}_{s}$, was found to decrease with the increase in zinc substitution. Fourier transform infrared spectroscopy (FTIR) spectra of the $\mathrm{Ni}_{1-\mathrm{x}} \mathrm{Zn}_{\mathrm{x}} \mathrm{Fe}_{2} \mathrm{O}_{4}$ with $\mathrm{x}=0,0.5,1$ in the range $400-4000 \mathrm{~cm}^{-1}$ were reported. The spinel structure and the crystalline water adsorption of $\mathrm{Ni}_{1-\mathrm{x}} \mathrm{Zn}_{\mathrm{x}} \mathrm{Fe}_{2} \mathrm{O}_{4}$ nanoparticles were studied by using FTIR.
\end{abstract}

Keywords: coprecipitation, fine particles, nanoferrites, spinel

\section{Introduction}

Magnetic properties of nanometer sized particles have attracted considerable attention in recent years because of their unique properties. For the preparation of magnetic fluids, nanoparticles with a particle size of order of $10 \mathrm{~nm}$ and with a narrow size distribution were required ${ }^{1}$. However, the size of the magnetic particle was decreased below a critical length, domain formation was no longer energetically favored and the particles existed as a single domain ${ }^{2}$. Magnetic nanoparticles have aroused increasing interest among researchers of various fields due to their extensive applications such as information storage system, medical diagnostics, ferrofluid technology, etc., ${ }^{3-7}$. This is mainly because the properties of nanoparticles differ from those of the corresponding bulk material ${ }^{8-9}$. Zinc substituted mixed ferrites (Ni-Zn) chosen here is highly sensitive to temperature. Ferrofluids constituted by these ferrites may be good candidates to be used as liquid carriers in heat exchangers using magneto caloric energy conversion ${ }^{10,11}$. It is well known that the magnetic property can be altered by the addition of zinc. Addition of zinc also affects the lattice parameter $\left(a_{0}\right)$. Various preparation techniques, such as sol-gel pyrolysis method ${ }^{12}$ hydrothermal technique ${ }^{13}$ and mechanical alloying ${ }^{14}$ has been used to prepare ferrite nanoparticles. But coprecipitation method is considered to be an economical way of producing fine particles ${ }^{15,16}$. The physical properties of nanoparticles are of current interest due to the size-dependent behavior observed in the nanometer length scale and high crystallinity. Preparation and properties of Ni-Zn ferrites have been reported only for a particular value of $\mathrm{x}$ or limited values. Jeyadevan et al. ${ }^{17}$ successfully prepared nearly monodispersed single-domain Nickel ferrite particles, which could be used for the high-density recording media. Morais et al. ${ }^{18}$ reported the possibility of controlling the size of nanoparticles using different stirring speeds. Temperature sensitive magnetic fluid having $\mathrm{Ni}_{0.3} \mathrm{Zn}_{0.7} \mathrm{Fe}_{2} \mathrm{O}_{4}$ particles was used for the study of thermal convection ${ }^{10}$. Hydrocarbon based Nickel ferrofluid was also reported ${ }^{19}$. A.kale et al. ${ }^{20}$ synthesized $\mathrm{Ni}_{1-\mathrm{x}} \mathrm{Zn}_{\mathrm{x}} \mathrm{Fe}_{2} \mathrm{O}_{4}$ nanoparticles with $\mathrm{x}$ varying from 0.1 to 0.5 . To the best of our knowledge complete range of $\mathrm{Ni}_{1-\mathrm{x}} \mathrm{Zn}_{\mathrm{x}} \mathrm{Fe}_{2} \mathrm{O}_{4}$ with $\mathrm{x}$ varying from 0 to 1.0 have been reported for nano particles. In the present work, we study the $\mathrm{Ni}_{1-\mathrm{x}} \mathrm{Zn}_{\mathrm{x}} \mathrm{Fe}_{2} \mathrm{O}_{4}$ with $\mathrm{x}$ varying from 0 to 1.0. The influence of zinc substitution on the crystallites size and magnetic properties depends on the preparation condition also. Here we report the modified preparation condition for the production of fine particles of $\mathrm{Ni}_{1-\mathrm{x}} \mathrm{Zn}_{\mathrm{x}} \mathrm{Fe}_{2} \mathrm{O}_{4}$ with $\mathrm{x}$ varying from 0 to 1.0. Structural and magnetic properties of Ni-Zn ferrite with $\mathrm{x}$ varying from 0 to 1.0 have also been discussed.

\section{Experimental Procedure}

\subsection{Synthesis of $\mathrm{Ni}_{1-x} \mathrm{Zn}_{x} \mathrm{Fe}_{2} \mathrm{O}_{4}$ nanoparticles}

The magnetization of substituted ferrite nano particles synthesized by coprecipitation depends mostly on parameters such as reaction temperature, $\mathrm{pH}$ of the suspension, initial molar concentration etc. ${ }^{21}$. Ultra fine particles of $\mathrm{Ni}_{1-\mathrm{x}} \mathrm{Zn}_{\mathrm{x}} \mathrm{Fe}_{2} \mathrm{O}_{4}$ with $\mathrm{x}$ varying from 0 to 1.0 were prepared by co-precipitating aqueous solutions of $\mathrm{NiCl}_{2}, \mathrm{ZnCl}_{2}$ and $\mathrm{FeCl}_{3}$ mixtures respectively in alkaline medium. The mixed solution of $\mathrm{NiCl}_{2}, \mathrm{ZnCl}_{2}$ and $\mathrm{FeCl}_{3}$ in their respective stoichiometry $(100 \mathrm{~mL}$ of $0.5 \mathrm{M} \mathrm{NiCl}_{2}, 100 \mathrm{~mL}$ of $0.5 \mathrm{M} \mathrm{ZnCl}_{2}$ and $100 \mathrm{~mL}$ of $2 \mathrm{M} \mathrm{FeCl}_{3}$ in the case of $\mathrm{Ni}_{0.5} \mathrm{Zn}_{0.5} \mathrm{Fe}_{2} \mathrm{O}_{4}$ and similarly for the other values of $\mathrm{x}$ ) was prepared and kept at $60{ }^{\circ} \mathrm{C}$. This mixture was added to the boiling solution of $\mathrm{NaOH}$ ( $0.63 \mathrm{M}$ dissolved in $1200 \mathrm{~mL}$ of distilled water) 
within 10 seconds under constant stirring. Nano ferrites are formed by conversion of metal salts into hydroxides, which take place immediately, followed by transformation of hydroxides into ferrites. At first solid hydroxides of metals in the form of fine particles were obtained by the coprecipitation of metal cations in alkaline medium (coprecipitation step) (Equations 1 and 2).

$$
\begin{aligned}
& (1 \quad \mathrm{x}) \mathrm{Ni}^{2+}+\mathrm{xZn}^{2+}+2 \mathrm{Fe}^{3+}+8 \mathrm{OH}^{-} \rightarrow \\
& (1-\mathrm{x}) \mathrm{Ni}(\mathrm{OH})_{2} \cdot \mathrm{xZn}(\mathrm{OH})_{2} \cdot 2 \mathrm{Fe}(\mathrm{OH})_{3} \downarrow
\end{aligned}
$$

The solid solution of metal hydroxides was transformed to complex zinc substituted ferrites when subjected to heating in the alkaline medium (ferritization step).

$$
\begin{aligned}
& (1-\mathrm{x}) \mathrm{Ni}(\mathrm{OH})_{2} \cdot \mathrm{xZn}(\mathrm{OH})_{2} \cdot 2 \mathrm{Fe}(\mathrm{OH})_{3} \stackrel{\begin{array}{c}
\text { heated in } \\
\text { alkaline medium }
\end{array}}{\longrightarrow} \\
& \mathrm{Ni}_{(1-\mathrm{x})} \mathrm{Zn}_{\mathrm{x}} \mathrm{Fe}_{2} \mathrm{O}_{4} \cdot \mathrm{nH}_{2} \mathrm{O}
\end{aligned}
$$

The solutions were maintained at $85^{\circ} \mathrm{C}$ for one hour. This duration was sufficient for the transformation of hydroxides into spinel ferrite (dehydration and atomic rearrangement involved in the conversion of intermediate hydroxide phase into ferrite) ${ }^{21}$. Sufficient amount of fine particles were collected at this stage by using magnetic separation. These particles were washed several times with distilled water followed by acetone and dried at room temperature.

\subsection{Particle characterization}

The X-ray diffraction (XRD) patterns of the samples were recorded on a Philips ${ }^{\circledR}$ PANALYTICAL X' PERT PRO X-ray powder diffractometer using $\mathrm{Cu} \mathrm{K} \propto(\lambda=1.54060 \AA)$ radiation. Slow scans of the selected diffraction peaks were carried out in step mode (step size $0.05^{\circ}$, measurement time 5 seconds, measurement temperature $25^{\circ} \mathrm{C}$, standard: Si powder). The crystallite size of the nanocrystalline samples was measured from the X-ray line broadening analyses using Debye- Scherrer formula after accounting for instrumental broadening (Equation 3):

$$
\mathrm{D}_{\mathrm{XRD}}=\frac{0.89 \lambda}{\beta \cos \theta}
$$

where $\lambda$ - wavelength of X-ray used in $\AA, \beta$ - FWHM in radians in the $2 \theta$ scale, $\theta$ - the Bragg angle, $\mathrm{D}_{\mathrm{XRD}}$ - crystallite size in $\mathrm{nm}^{22}$. The lattice constant $\left(a_{0}\right)$ was determined for various values of zinc content. $\mathrm{Ni}-\mathrm{Zn}$ ferrite has a spinel structure ${ }^{20}$.

\subsection{Magnetic measurements}

Room temperature magnetic measurements with a maximum magnetic field of $1194.15 \mathrm{kA} . \mathrm{m}^{-1}$ were carried out using a Lakeshore vibrating sample magnetometer (VSM) (model 7404) and parameters like specific saturation magnetization $\left(\mathrm{M}_{\mathrm{s}}\right)$, coercive force $\left(\mathrm{H}_{\mathrm{c}}\right)$ and remanence $\left(\mathrm{M}_{\mathrm{r}}\right)$ were evaluated.

\subsection{Spectral measurements}

FTIR spectra were recorded for the dried samples of $\mathrm{Ni}_{1-x} \mathrm{Zn}_{x} \mathrm{Fe}_{2} \mathrm{O}_{4}$ with $\mathrm{x}$ varying from 0 to 1.0 with an ABB BOMEM 104 FTIR (range $400-4000 \mathrm{~cm}^{-1}$ ) spectrometer. The dried samples were in $\mathrm{KBr}$ matrix, and spectra were measured according to transmittance method. The spectra were resolved with a resolution of $4 \mathrm{~cm}^{-1}$.

\section{Result and Discussion}

\subsection{Physical characterization}

Generally, XRD can be used to characterize the crystallinity of nanoparticles, and it gives theaverage diameters of all the nanoparticles. The precipitated fine particles were characterized by XRD for structural determination and estimation of crystallite size. XRD patterns were analyzed and indexed using powder X software ${ }^{23}$. All experimental peaks were matched with the theoretically generated one and indexed. The lattice constant $\left(a_{0}\right)$ was computed using the ' $\mathrm{d}$ ' value and with their respective ( $\mathrm{h} \mathrm{k} \mathrm{l)} \mathrm{parameters.}$ Analysis of the diffraction pattern confirms the formation of cubic spinel structure for all the samples. The strongest reflection comes from the (311) plane, which denotes the spinel phase. All the compositions had a spinel structure. The peaks indexed to (220), (311), (400), (422), (511) and (440) planes of a cubic unit cell, correspond to cubic spinel structure. The calculated lattice constant $\left(\mathrm{a}_{\mathrm{o}}\right)$, identified the samples to be cubic spinel and was refined using Powder X. The XRD pattern for $\mathrm{Ni}_{1-\mathrm{x}} \mathrm{Zn}_{\mathrm{x}} \mathrm{Fe}_{2} \mathrm{O}_{4}$ with $\mathrm{x}=0,0.2,0.4$, 0.6, 0.8 and 1 is shown in Figure 1.The peaks of (220), (311), (400), (422), (511) and (440) have been deconvoluted to Lorentzian curves, using Peak Fit software for the determination of FWHM value of the indexed peaks ${ }^{24}$. The lattice constant was found to increase from 8.212 to $8.462 \AA$ with the increase in zinc concentration. The lattice constant $\left(\mathrm{a}_{\mathrm{o}}\right.$ ) increased with the increase in $\mathrm{Zn}$ content, which suggested the formation of a compositionally homogeneous solid solution and was found to be within the range of the lattice constants of $\mathrm{ZnFe}_{2} \mathrm{O}_{4}$ and $\mathrm{NiFe}_{2} \mathrm{O}_{4}$. This increase could be also attributed to the substitution of the large sized $\mathrm{Zn}$ cation for the small sized $\mathrm{Ni}$ cation. The lattice constant obtained for $\mathrm{NiFe}_{2} \mathrm{O}_{4}(8.384 \AA)$ is close to that known of bulk $\mathrm{NiFe}_{2} \mathrm{O}_{4}(8.395 \AA)^{[3]}$. The lattice constant for $\mathrm{Ni}-\mathrm{Zn}$ ferrites reported by R. Anantharaman et al. ${ }^{25}$ is very close to the present experimental values. Figure 2 shows that the lattice constant

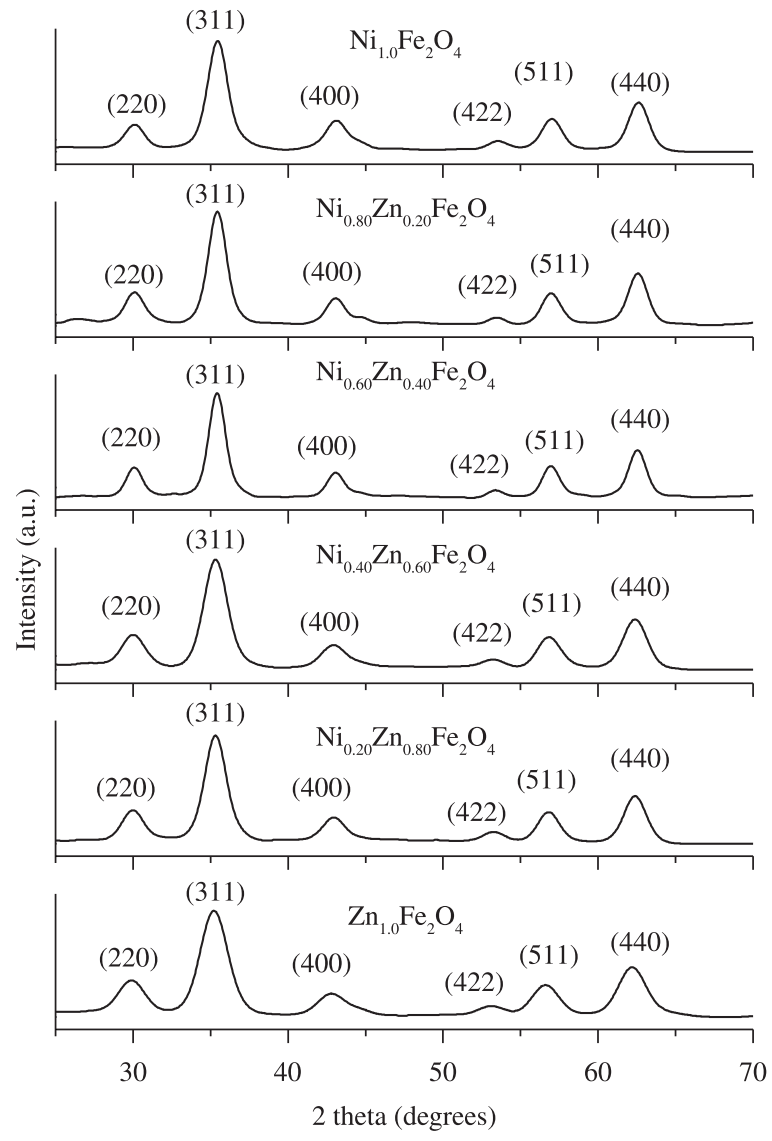

Figure 1. Indexed $\mathrm{x}$-ray diffraction pattern for $\mathrm{Ni}_{1-\mathrm{x}} \mathrm{Zn}_{\mathrm{x}} \mathrm{Fe}_{2} \mathrm{O}_{4}$ with $\mathrm{x}=0,0.2$, $0.4,0.6,0.8$ and 1.0 . 


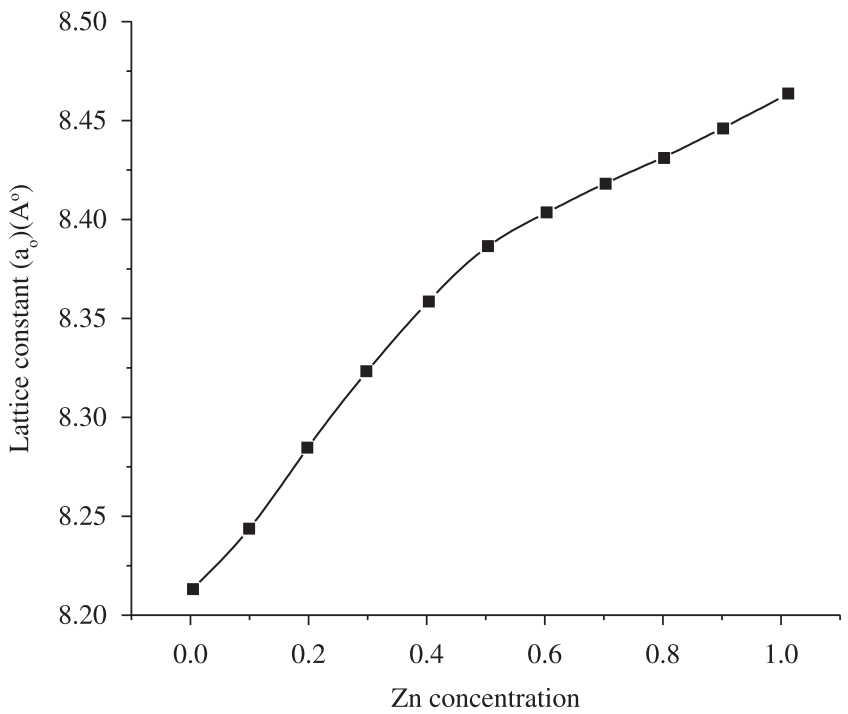

Figure 2. Variation of Lattice constant $(\mathrm{ao})(\AA)$ with $\mathrm{Zn}$ concentration for $\mathrm{Ni}_{1-x} \mathrm{Zn}_{\mathrm{x}} \mathrm{Fe}_{2} \mathrm{O}_{4}$ with $\mathrm{x}$ varying from 0 to 1.0 .

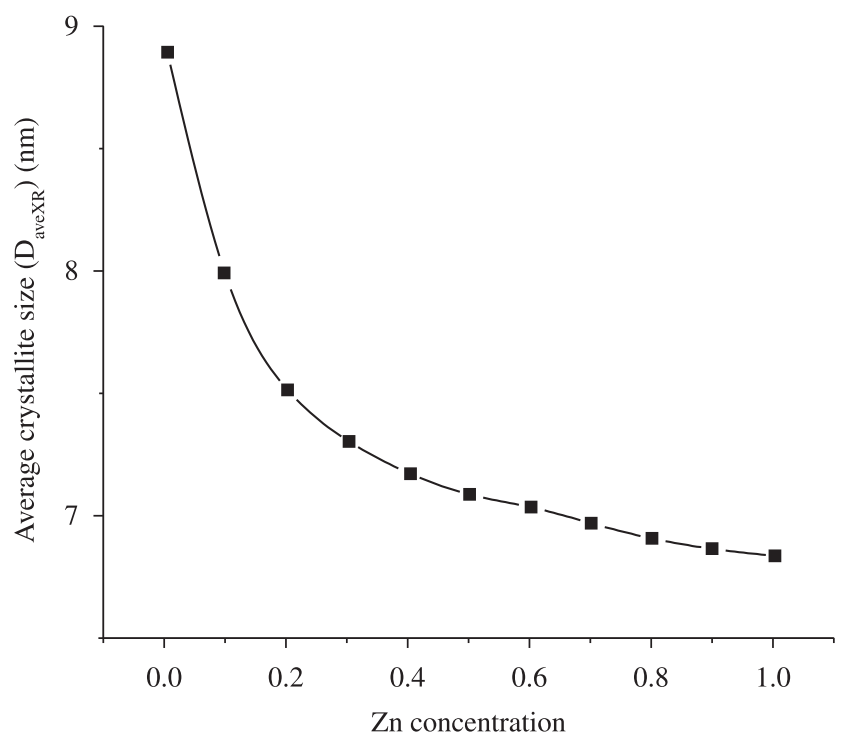

Figure 3. Variation of the average crystallize size with $\mathrm{Zn}$ concentration for $\mathrm{Ni}_{1-\mathrm{x}} \mathrm{Zn}_{\mathrm{x}} \mathrm{Fe}_{2} \mathrm{O}_{4}$ with $\mathrm{x}$ varying from 0 to 1.0

increases with increase in zinc concentration. The crystallite size $\left(D_{\text {XRD }}\right)$ was estimated bythe Debye -Scherrer formula ${ }^{23}$ using the full width at half maximum value of the respective indexed peaks. The average crystallite size $\left(D_{\text {aveXR }}\right)$ decreases from 8.95 to $6.92 \mathrm{~nm}$ when the partial substitution of zinc increases $(x=0$ to $x=1.0$ ). This value is close to the crystallite size reported by A. Kale et al. ${ }^{20}$. Though all the samples were prepared under identical condition, the crystallite size was not the same for all $\mathrm{Zn}$ concentrations. This was probably due to the preparation condition followed here which gave rise to different rate of ferrite formation for different concentrations of zinc, favoring the variation of crystallite size. The variation of average crystallite size with the zinc concentration is given in Figure 3 . Ferrofluids can be conveniently prepared by making use of particles in this size range.

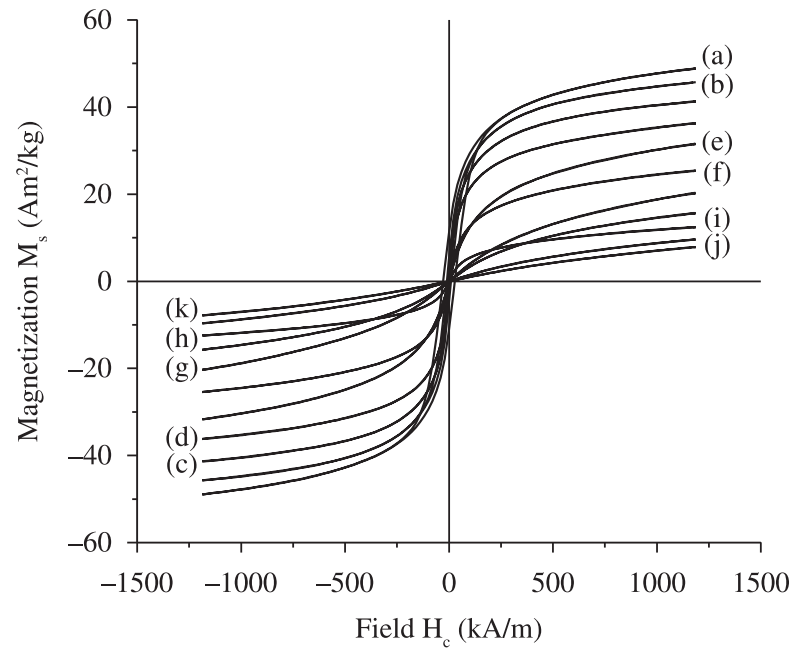

Figure 4. Room temperature magnetization curve of (a) $\mathrm{N}_{1.0} \mathrm{Fe}_{2} \mathrm{O}_{4}$,

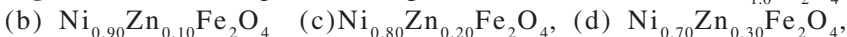
(e) $\mathrm{Ni}_{0.60} \mathrm{Zn}_{0.40} \mathrm{Fe}_{2} \mathrm{O}_{4}$, (f) $\mathrm{Ni}_{0.50} \mathrm{Zn}_{0.50} \mathrm{Fe}_{2} \mathrm{O}_{4}$, (g) $\mathrm{Ni}_{0.40}^{0.70} \mathrm{Zn}_{0.60} \mathrm{Fe}_{2} \mathrm{O}_{4}$, (h) $\mathrm{Ni}_{0.30} \mathrm{Zn}_{0.70} \mathrm{Fe}_{2} \mathrm{O}_{4}$, (i) $\mathrm{Ni}_{0.20} \mathrm{Zn}_{0.80} \mathrm{Fe}_{2} \mathrm{O}_{4}$, (j) $\mathrm{Ni}_{0.10} \mathrm{Zn}_{0.90} \mathrm{Fe}_{2} \mathrm{O}_{4}$ and (k) $\mathrm{Zn}_{1.0} \mathrm{Fe}_{2} \mathrm{O}_{4}$

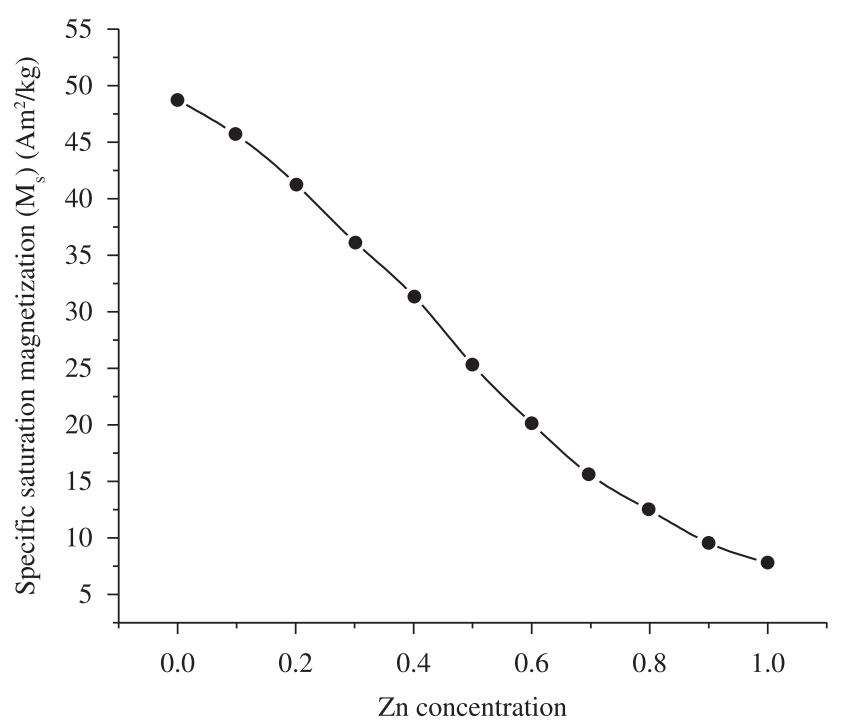

Figure 5. Variation of specific saturation magnetization with Zn concentration for $\mathrm{Ni}_{1-\mathrm{x}} \mathrm{Zn}_{\mathrm{x}} \mathrm{Fe}_{2} \mathrm{O}_{4}$ with $\mathrm{x}$ varying from 0 to 1.0 .

\subsection{Magnetic measurements}

In the cubic system of ferrimagnetic spinels, the magnetic order is mainly due to a super exchange interaction mechanism occurring between the metal ions in the A and B sublattices. The substitution of nonmagnetic ion such as $\mathrm{Zn}$, which has a preferential A site occupancy results in the reduction of the exchange interaction between $A$ and $B$ sites. Hence, by varying the degree of zinc substitution, it is possible to vary magnetic properties of the fine particles. Figure 4 shows the room temperature hysteresis loop of the powder samples for various zinc substitutions. From Figure 4 it can be seen that the variation pattern of specific saturation magnetization $\left(\mathrm{M}_{\mathrm{s}}\right)$ as a function of $\mathrm{Zn}$ content shows an increase for $\mathrm{Zn}$ substitutionsand reaches a maximum value of $48.72 \mathrm{Am}^{2} \cdot \mathrm{Kg}^{-1}$ at $1194.15 \mathrm{kA} \cdot \mathrm{m}^{-1}$ for $\mathrm{x}=0$. The changes in the specific saturation magnetization with the degree of zinc substitution 
are given in Figure 5. It is clear from the Figure 4 that the particles do not show any saturation for $\mathrm{x}=0.9$ and 1.0 .even at $1194.15 \mathrm{kA} \cdot \mathrm{m}^{-1}$ and it almost behaves linear. The changes in magnetic property of $\mathrm{M}_{\mathrm{s}}$, is due to the influence of the cationic stoichiometry and their occupancy in the specific sites. In addition, formation of dead layer on the surface, existence of random canting of particle surface spins ${ }^{24,26}$, non saturation effects due to random distribution of particle size, deviation from the normal cation distribution, presence of adsorbed water etc. ${ }^{11}$ might be the cause for the reduction of magnetic properties of nanoparticles. Reaction temperature of $85^{\circ} \mathrm{C}$ and $12.0 \mathrm{pH}$ were used to synthesis fine particles $\mathrm{Ni}_{1.0} \mathrm{Fe}_{2} \mathrm{O}_{4}(8.95 \mathrm{~nm}$ in size $)$ having highest specific saturation magnetization of $48.72 \mathrm{Am}^{2} \cdot \mathrm{Kg}^{-1}$. The deviation of cation distribution in nanoparticles from the bulk, influences the temperature dependence of magnetization. The hysteresis curve (Figure 4) recorded at room temperature shows very low remanence, coercivity for large zinc concentration proves that the particles are super paramagnetic at room temperature.

\subsection{Spectral measurements}

The FTIR spectra for $\mathrm{Fe}_{3} \mathrm{O}_{4}$ and for $\mathrm{Ni}_{1-\mathrm{x}} \mathrm{Zn}_{\mathrm{x}} \mathrm{Fe}_{2} \mathrm{O}_{4}$ with $\mathrm{x}=0,0.5$ and 1 are shown in Figure 6. By overlaying the FTIR spectra for $\mathrm{Fe}_{3} \mathrm{O}_{4}$ and for $\mathrm{Ni}_{1-\mathrm{x}} \mathrm{Zn}_{\mathrm{x}} \mathrm{Fe}_{2} \mathrm{O}_{4}$ with $\mathrm{x}=0,0.5$ and 1.0, the spectral similarities are observed. The broad feature between $3441.43-3219.90 \mathrm{~cm}^{-1}$ is due to $\mathrm{O}-\mathrm{H}$ stretch which corresponds to the hydroxyl groups attached by the hydrogen bonds to the iron oxide surface and the water molecules chemically adsorbed to the magnetic particle surface (associated water content) ${ }^{27}$. From these results, it appears that the hydroxyl groups are retained in the samples
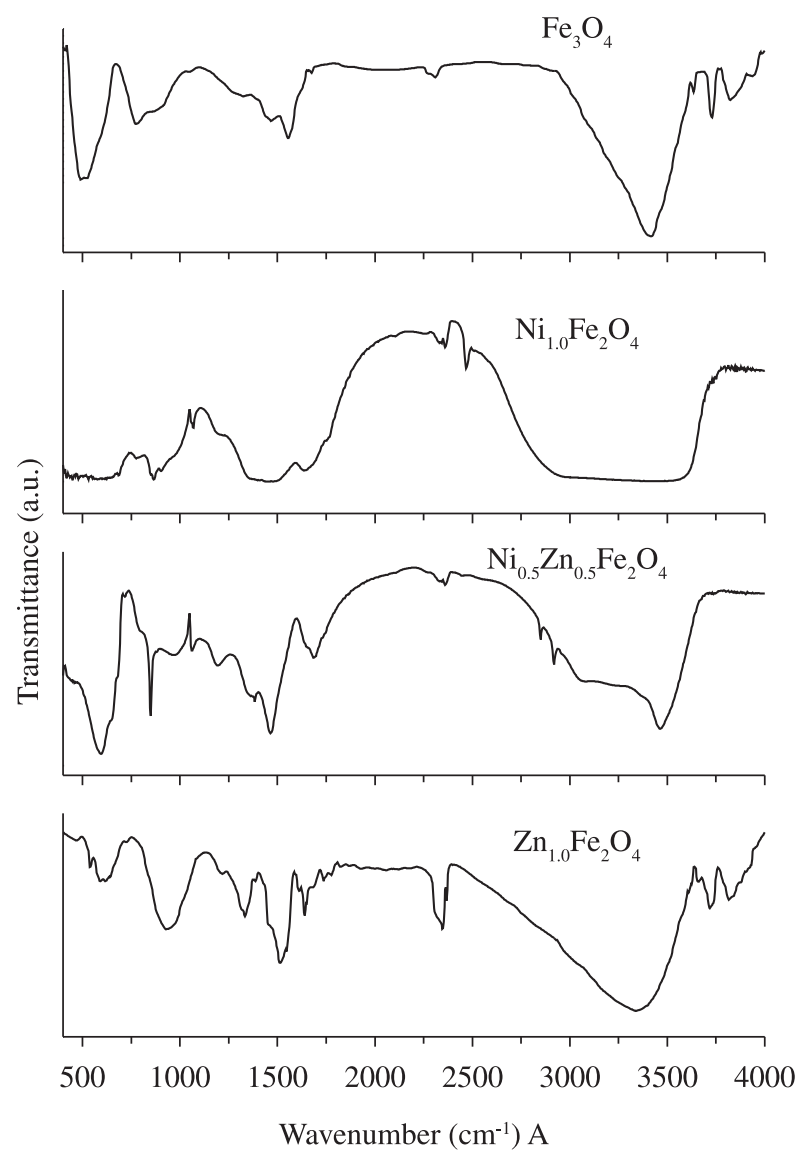

Figure 6. FTIR spectra for $\mathrm{Fe}_{3} \mathrm{O}_{4}$ and for $\mathrm{Ni}_{1-\mathrm{x}} \mathrm{Zn}_{\mathrm{x}} \mathrm{Fe}_{2} \mathrm{O}_{4}$ with $\mathrm{x}=0,0.5$ and 1.0 . during the preparation of the uncoated $\mathrm{Ni}_{1-\mathrm{x}} \mathrm{Zn}_{\mathrm{x}} \mathrm{Fe}_{2} \mathrm{O}_{4}$ spinel ferrites prepared by coprecipitation method. Ghose et al. ${ }^{28}$ have reported that the presence of some hydroxyl ions are completely removed when the sample is sintered at temperatures $\geq 973 \mathrm{~K}^{29}$. The $\mathrm{O}-\mathrm{H}$ in-plane and out-of-plane bonds appear at $1537.80-1500.31 \mathrm{~cm}^{-1}$ and $960.03-874.235 \mathrm{~cm}^{-1}$, respectively. The spectrum of the uncoated sample $\mathrm{Ni}_{0.90} \mathrm{Zn}_{0.10} \mathrm{Fe}_{2} \mathrm{O}_{4}$ shows a strong band from 635.57 to $573.51 \mathrm{~cm}^{-1}$ due to $\mathrm{Fe}_{3} \mathrm{O}_{4}{ }^{29}$. The transmittance waveband from 635.57 to $573.51 \mathrm{~cm}^{-1}$, which corresponds to the metal-oxygen bonds may be due to $\mathrm{ZnO}, \mathrm{NiO}$ and $\mathrm{Fe}_{3} \mathrm{O}_{4}$. This is in good agreement with Zins et al. ${ }^{11,30-33}$.

\section{Conclusion}

Preparation technique suitable for preparation of $\mathrm{Ni}-\mathrm{Zn}$ substituted ferrite nanoparticles is reported. $\mathrm{Ni}_{1-\mathrm{x}} \mathrm{Zn}_{\mathrm{x}} \mathrm{Fe}_{2} \mathrm{O}_{4}$ nanoparticles can be prepared by the coprecipitation method for the full range of composition with $\mathrm{x}$ varying from $\mathrm{x}=0$ to1. The formation of $\mathrm{Ni}_{1-\mathrm{x}} \mathrm{Zn}_{\mathrm{x}} \mathrm{Fe}_{2} \mathrm{O}_{4}$ was confirmed by the X-ray diffraction. The lattice constant was found to increase with the increase in zinc concentration. The average crystallite size $\left(\mathrm{D}_{\text {aveXR }}\right)$ decreased when the partial substitution of zinc increased ( $\mathrm{x}=0$ to $\mathrm{x}=1.0)$. The specific saturation magnetization was found to decrease with the increase in zinc substitution. Low coercivity was observed for the high $\mathrm{Zn}$ concentration for the $\mathrm{Ni}-\mathrm{Zn}$ ferrite nanoparticles. In the present work, the samples prepared by coprecipitation method showed superparamagnetic behavior, which was documented by the hysteresis loop, measured at room temperature. Here the $\mathrm{NiFe}_{2} \mathrm{O}_{4}$ prepared by coprecipitation method shows that it is a not very hard magnetic material since the hysteresis loop is very small and it is known that $\mathrm{ZnFe}_{2} \mathrm{O}_{4}$ is a soft magnetic material. This soft-magnetic nanoparticles have interesting applications, in magnetic coatings and in the preparation of Ferrofluids. FTIR was used to confirm the formation of $\mathrm{Fe}-\mathrm{O}$ bonds and presence of the associated water content in the samples.

\section{References}

1. Rosensweig RE. Ferrohydrodynamics. Cambridge: University Press; 1985.

2. Kittel C. Theory of the Structure of Ferromagnetic Domains in Films and Small Particles. Physical Review. 1946; 70(11-12):965-971.

3. Yeong I, Kim KD and Lee CS. Synthesis and characterization of $\mathrm{CoFe} 2 \mathrm{O} 4$ magnetic nanoparticles prepared by temperature-controlled coprecipitation method. Physica B: Physics of Condensed Matter. 2003; $337(1-4): 42-51$.

4. Li S, Liu L, John VT, O'Connor CJ and Harris VG. Cobalt-ferrite nanoparticles: correlations between synthesis procedures, structural characteristics and magnetic properties. IEEE Transactions on Magnetics (New York). 2001; 37(4):2350-2352.

5. Didukh P, Greneche JM, Slawska-Waniewska A, Fannin PC and Casas LI. Surface effects in $\mathrm{CoFe} 2 \mathrm{O} 4$ magnetic fluids studied by Mössbauer spectrometry. Journal of Magnetism and Magnetic Materials (Amsterdam). 2002; (242-245):613-616. part 1.

6. Neveu S, Bee A, Robineau M and Talbot D. Supramolecular assemblies of gold nanoparticles induced by hydrogen bond interactions. Journal of Colloid and Interface Science (New York). 2002; 255(2):293-298.

7. Pathmamanoharan $\mathrm{C}$ and Philipse AP. Preparation and properties of monodisperse magnetic cobalt colloids grafted with polyisobutene. Journal of Colloid and Interface Science (New York). 1998; 205:340-353.

8. Rao CNR and Cheetam AK. Science and Technology of Nanomaterials: Current Status and Future Prospects. Journal of Materials Chemistry. 2001; (11):2887-2894.

9. Ozin GA. Nanochemistry: synthesis in diminishing dimensions. Advanced Matterials (Weinheim). 1992; 4(10):612-649. 
10. Fujita T, Mamiya M and Jeyadevan B. Basic study of heat convection pipe using the developed temperature sensitive magnetic fluid. Journal of Magnetism and Magnetic Materials (Amsterdam). 1990; 85(1-3):203-206.

11. Auzans E, Zins D, Blums E and Massart R. Synthesis and properties of Mn-Zn ferrite ferrofluids. Journal of Materials Science (Norwell). 1999; 34(6):1253-1260.

12. Lee GJ, Minlee $\mathrm{H}$ and Kim CS. Magnetic properties of $\mathrm{CoFe} 2 \mathrm{O} 4$ powders and thin films grown by a sol-gel method. Journal of Magnetism and Magnetic Materials (Amsterdam). 1998; 177-181:900-902. Part 2.

13. Davis KJ, Grady KO and Morup S. The observation of multi-axial anisotropy in ultrafine cobalt ferrite particles used in magnetic fluids. Journal of Magnetism and Magnetic Materials (Amsterdam). 1995; 149(1-2):14-18.

14. Ding J, McCormick PG and Street R. Formation of spinel Mn-ferrite during mechanical alloying. Journal of Magnetism and Magnetic Materials (Amsterdam). 1997; 171(3):309-314.

15. Upadhyay RV, Metha RV, Parekh K, Srinivas D and Pant RP. Gdsubstituted ferrite ferrofluid: a possible candidate to enhance pyromagnetic coefficient. Journal of Magnetism and Magnetic Materials (Amsterdam). 1999; 201(1):129-132.

16. Shi Y, Ding J, Liu X and Wang J. NiFe2O4 ultrafine particles prepared by co-precipitation/mechanical alloying. Journal of Magnetism and Magnetic Materials (Amsterdam). 1999; 205(2-3):249-254.

17. Chinnasamy CN, Senouse M, Jeyadevan B, Perales-Perez O, Shinoda $\mathrm{K}$ and Tohiji K. Synthesis of size-controlled cobalt ferrite particles with high coercivity and squareness ratio. Journal of Colloid and Interface Science (New York). 2003; 263(1):80-83.

18. Morais PC, Garg VK, Oliveira AC, Silva LP, Azevedo RB, Silva AML, et al. Synthesis and characterization of size-controlled cobalt-ferritebased ionic ferrofluids. Journal of Magnetism and Magnetic Materials (Amsterdam). 2001; 225(1-2):37-40.

19. Hoon SR, Kilner M, Russel GJ and Tanner BK. Preparation and properties of Ni-Fe magnetic fluids. Journal of Magnetism and Magnetic Materials (Amsterdam). 1983; 39(2-3):107-110.

20. Kale A, Gubbala S and Misra RDK. Magnetic behaviour of nanocrystaline nickel ferrite synthesized by the reverse micelle technique. Journal of Magnetism and Magnetic Materials (Amsterdam). 2004; 277(3):350-358.

21. Jeyadevan B, Chinnasamy CN, Shinoda K and Tohji K. Mn-Zn ferrite with higher magnetization for temperature sensitive magnetic fluid. Journal of Applied Physics (New York). 2003; 93(10):8450-8452.
22. Cullity BD. Elements of X-ray diffraction. 2nd ed. London: Addison Wesley; 1978.

23. Dong C. A Windows-95-based program for powder X-ray diffraction data processing. PowderX Applied Crystallography (Copenhagem). 1999; 32(4):838.

24. Han DH, Wang JP and Lou HL. Crystallite size effect on saturation magnetizaton of fine ferrimagnetic particles. Journal of Magnetism and Magnetic Materials (Amsterdam). 1994; 136(1-2):176-182.

25. Anantharaman MR, Jagatheesan S, Malini KA, Sindhu S, Narayanasamy A, Chinnasamy CN, Jacobs JP, Reijne S, Seshan K, Smits RHH, Brongersma $\mathrm{HH}$ et al. On the magnetic properties of ultra-fine zinc ferrites. Journal of Magnetism and Magnetic Materials (Amsterdam). 1998; 189(1):83-88.

26. Kale GM and Asokan T. Electrical properties of cobalt-zinc ferrites. Applied Physics Letters (New York). 1993; 62(19):2324-2325.

27. Creanga D and Calugaru G. Physical investigations of a ferrofluid based on hydrocarbons. Journal of Magnetism and Magnetic Materials (Amsterdam). 2005; 289:81-83.

28. Dey S and Ghose J. Synthesis, characerization and magnetic studies on nanocrystalline $\mathrm{Co}_{0.2} \mathrm{Zn}_{0.8} \mathrm{Fe}_{2} \mathrm{O}_{4}$. Materials Research Bulletin (New York) 2003; 38(11-12):1653-1660.

29. Ahn Y, Choi EJ and Kim EH. Superparamagnetic Relaxation in Cobalt Ferrite Nanoparticles Synthesized from Hydroxide Carbonate Precursors. Reviews on Advanced Materials Science. 2003; 5:477-480.

30. Ma M, Zhang Y, Yu W, Shen HY, Zhang and Gu N. Preparation and characterization of magnetite nanoparticles coated by amino silane. Colloids and Surfaces A: Physicochemical and Engineering Aspects. 2003; 212(2-3): 219-226

31. Ahmed SR and Kofinas P. Magnetic properties and morphology of diblock copolymer templated ferrimagnetic cobalt oxide nanoparticles. Journal of Magnetism and Magnetic Materials (Amsterdam). 2005; 288:219-223.

32. Ishikawa T, Nakazaki H, Yasukawa A, Kandori K and Seto M. Influences of $\mathrm{Co}^{2+}, \mathrm{Cu}^{2+}$ and $\mathrm{Cr}^{3+}$ íons on the formation of magnetite. Corrosion Science (Oxford). 1999; 41(8):1665-1680.

33. Wu N, Fu L, Su M, Aslam M, Wong KC and Dravid VP. Interaction of Fatty Acid Monolayers with Cobalt Nanoparticles. Nano Letters (Washington, DC). 2004; 4(2):383-386. 
